\title{
Platelet-derived growth factor (PDGF) and PDGF receptors in rat corpus cavernosum: changes in expression after transient in vivo hypoxia
}

\author{
A Aversa ${ }^{1,2}, \mathrm{~S}$ Basciani $^{3}$, P Visca $^{4}$, M Arizzi ${ }^{3}$, L Gnessi $^{3}$, \\ G Frajese $^{2}$ and A Fabbri ${ }^{2}$ \\ ${ }^{1}$ AFaR-CRCCS, Ospedale Fatebenefratelli-Isola Tiberina, 00186 Rome, Italy \\ ${ }^{2}$ Cattedra di Endocrinologia, Università degli Studi 'Tor Vergata', Ospedale Fatebenefratelli-Isola Tiberina, 00186 Rome, Italy \\ ${ }^{3}$ Dipartimento Fisiopatologia Medica, Università degli Studi ‘La Sapienza' 00161 Rome, Italy \\ ${ }^{4}$ Servizio di Anatomia Patologica-IFO, Polo Oncologico 'Istituto Regina Elena', 00100 Rome, Italy \\ (Requests for offprints should be addressed to A Aversa, Cattedra di Endocrinologia, Università di Roma 'Tor Vergata', Via di Torvergata 135, \\ 00133 Roma, Italy; Email: amfaversa@yahoo.com)
}

\begin{abstract}
Platelet-derived growth factor (PDGF) overactivity has been implicated in atherosclerosis and several fibrotic conditions including lung and kidney fibrosis, liver cirrhosis and myelofibrosis. Low oxygen tension (hypoxia) is a known stimulus for transcriptional induction of PDGF ligand and receptor genes in different tissues. We studied the expression and localization of PDGF-A, PDGF-B, and PDGF receptor (PDGFR) $\alpha$ and $-\beta$ subunits in adult rat isolated corpus cavernosum (CC) under generalized transient hypoxia $\left(\mathrm{pO}_{2} 10 \%\right)$ in comparison with normoxic conditions. Semi-quantitative RT-PCR analysis of mRNA extracted from rat penis showed higher amounts of PDGF-A, PDGF-B and PDGFR- $\beta$ mRNA
\end{abstract}

transcripts in hypoxic versus normoxic animals. The immunohistochemical analysis showed that the localization of PDGF subunits and PDGFR- $\beta$ was confined to the cytoplasm of the perivascular smooth muscle cells, endothelium and trabecular fibroblasts. Our findings indicate that transient low oxygen tension induces PDGF overexpression in rat CC, which in the long term may lead to an increase of connective tissue production. We suggest that a local impairment of the PDGF/PDGFR system may contribute to CC fibrosis, which is an established cause of erectile dysfunction in man.

Journal of Endocrinology (2001) 170, 395-402

\section{Introduction}

Platelet-derived growth factor (PDGF) is a major mitogen for cells of mesenchymal origin, such as fibroblasts and smooth muscle cells. PDGF is widely expressed in normal and transformed cells and is produced by monocytes and macrophages, vascular endothelial and smooth muscle cells (Antoniades 1991, Heldin 1992). There are three PDGF isoforms ( $\mathrm{AA}, \mathrm{AB}$ and $\mathrm{BB}$ ) that exert their biological actions via binding to cell surface receptors $(\alpha$ and $\beta$ ) that belong to the protein tyrosine-kinase family of receptors (Williams 1989). PDGF-mediated events, which include chemoattraction, activation of inflammatory cells, vasoconstriction and influence on the synthesis or degradation of matrix constituents (Heldin 1992), are most likely exerted locally in an autocrine or paracrine manner and are involved in natural as well as pathological processes, such as neoplasia, atherosclerosis and fibrosis (Heldin 1992, Gnessi et al. 1993). Recently, immunohistochemical and electron microscopy studies showed that PDGF is highly expressed in penile tunica albuginea obtained from patients with veno-occlusive dysfunction and Peyronie's disease (Gentile et al. 1996), suggesting that it could be involved in the pathogenesis of these two conditions that are frequently associated with erectile dysfunction (ED) in men.

In vivo, the reduction in the environmental oxygen tension to which cells are exposed leads to physiological and, eventually, pathological consequences associated with differential expression of specific genes which encode for cytokines and growth factors thought to play key roles in the regulation of synthesis and assembly of connective tissue proteins (Gerritsen \& Bloor 1993, Bunn \& Poyton 1996). For example, in rat corpus cavernosum smooth muscle cells in culture hypoxia stimulates the expression of transforming growth factor $\beta_{1}$ (TGF- $\left.\beta_{1}\right)$, a pleotrophic cytokine that is known to induce extracellular matrix expression and inhibit growth and proliferation of vascular smooth muscle cells (Faller 1999). Indeed, in human corpus cavernosum smooth muscle cells, TGF- $\beta_{1}$ is a 
mitogen and induces a two- to fourfold increase in collagen synthesis (Moreland et al. 1995); also, it has been found to be overexpressed in tunica albuginea from men suffering venocclusive dysfunction (Nehra et al. 1996) and in plaques obtained from Peyronie's disease (El-Sakka et al. 1997).

In this study, we compared for the first time the expression of PDGF subunits and PDGF receptor mRNAs in corpora cavernosa (CC) isolated from adult rats both in normal conditions and after acute hypoxia $\left(\mathrm{pO}_{2}=\right.$ $10 \mathrm{mmHg}$ ). The immunohistochemical localization of PDGF-A, PDGF-B and PDGF receptor (PDGFR)- $\alpha$ and $-\beta$ subunits was also evaluated in comparison with that of the TGF- $\beta_{1}$.

\section{Materials and Methods}

\section{Hypoxic exposure and CC preparation}

Male Sprague-Dawley rats (55-60 days) purchased from Charles River Italia (Calco, Italy), were continuously gassed for $6 \mathrm{~h}$ with a mixture of $10 \% \mathrm{O}_{2}$ and $90 \% \mathrm{~N}_{2}$ (ten rats) or normal air (ten rats) in a $70 \times 60 \times 100 \mathrm{~cm}$ gas-tight box (Bucher et al. 1996); animals were conscious and had free access to food and water. At the end of the procedure decapitation was performed, blood was collected from the left ventricle for $\mathrm{pO}_{2}, \mathrm{sO}_{2}$ and $\mathrm{pCO}_{2}$ determination by hemogasanalysis (Franchini et al. 1994), and CC were rapidly prepared according to Broderick et al. (1994) with minor modifications. Briefly, rat penises were surgically removed and the corpus spongiosum and the urethra were excised. The CC tissues were carefully dissected free from the surrounding tunica albuginea and made available for RT-PCR and immunohistochemical studies. The Animal Care Committee of the University of Rome Medical School approved this protocol.

\section{RNA extraction and RT-PCR analysis}

Tissues mRNA were extracted by using a commercial kit (Micro-Fast-Track Kit, Invitrogen, San Diego, CA, USA). Reverse transcription was performed using an annealing temperature of $70{ }^{\circ} \mathrm{C}$ in a final volume of $25 \mu \mathrm{l}$ containing $250 \mathrm{mM}$ Tris- $\mathrm{HCl}, 375 \mathrm{mM} \mathrm{KCl}, 15 \mathrm{mM}$ $\mathrm{MgCl}_{2}, 50 \mathrm{mM}$ dithiothreitol (DTT), $0.5 \mathrm{mM}$ dNTPs, $0.5 \mu \mathrm{g}$ random hexamer oligonucleotide, $200 \mathrm{U}$ M-MLVRT, 26 U ribonuclease inhibitor (Promega, Madison, WI, USA). $\beta$-actin was used as a constutively expressed gene product for comparison of PDGFs and PDGFRs mRNA abundance between samples. A $0.5 \mu \mathrm{l}$ volume of the RT products was amplified with 2.5 units of Taq DNA polymerase (Promega) and $20 \mu \mathrm{M}$ specific rat $\beta$-actin primer (Table 1) in $50 \mu \mathrm{l}$ of reaction mix containing $500 \mathrm{mM} \mathrm{KCl}, 200 \mathrm{mM}$ Tris- $\mathrm{HCl}$, and $1.5 \mathrm{mM} \mathrm{MgCl}_{2}$ as follows: $94{ }^{\circ} \mathrm{C}, 1 \mathrm{~min} ; 58^{\circ} \mathrm{C}, 1 \mathrm{~min} ; 72{ }^{\circ} \mathrm{C}, 1 \mathrm{~min}$. To
Table 1 Primers utilized in PCR reactions

$$
5^{\prime}-3^{\prime} \text { sequence }
$$

Substance

PDGF-A

PDGF-A ${ }_{2}$

PDGF-B $_{1}$

PDGF- $B_{2}$

PDGF- $\alpha_{1}$

PDGF- $\alpha_{2}$

PDGF- $\beta_{1}$

PDGF- $\beta_{2}$

$\beta$-actin 1

$\beta$-actin 2
CCTGTGCCATCCGCAGGAAGAGA TTGGCCACCTTGACGCTGCGGTG GATCCGCTCCTTTGATGATC GTCTCACACTTGCATGCCAG CGACTCCAGATGGGAGTTCCC TGACATCCACTTCACAGGCA CACCATTTCGAGCACCTITGT AGGGCACTCCGAAGAGGTAA ATTGGCAATGAGCGGTTCCGC CTCCTGCTTGCTGATCCACATC
Position

215-239

418-441

1203-1223

$1617-1637$

1881-1902

2704-2724

28-49

684-704

2413-2437

$2727-2349$ ensure amplification in the exponential phase of PCR, reactions were temporarily halted at $20,25,30,35$ and 40 cycles, and $10 \mu \mathrm{l}$ of PCR products were removed from each tube (see Fig. 1). All products were analyzed by $1 \cdot 5 \%$ agarose gel electrophoresis and 30 cycles were chosen for further analysis. Quantitation of the signals was performed by densitometric analysis, using densitometry computer software (Kodak Digital Science ID Image Analysis Software, Eastman Kodak Company, Rochester, NY, USA). Dilution of RT products was made where necessary and the amplification procedure was repeated until all samples were standardized for $\beta$-actin content. After standardization, PCR was performed using appropriately diluted RT products in $50 \mu$ lof the reaction mix by utilizing $20 \mu \mathrm{M}$ of each rat PDGFs and PDGFRs primers (Table 1). For each gene examined, all primers were derived from separate exons and spanned at least one intron of genomic sequence, thus excluding the possibility of genomic DNA contamination. No PCR product was obtained with any of the set of primers in the absence of cDNA template (negative control) (Caprio et al. 1999). Thermocycling conditions were: initial denaturation for 3 min at $94^{\circ} \mathrm{C}, 30$ cycles of amplification (since levels of PCR products increased in a linear fashion for up to 35 cycles for PDGFs and PDGFRs, Fig. 1) with 1 min of denaturation at $94^{\circ} \mathrm{C}$, different annealing temperature for each pair of primers (Table 1), 1 min extension at $72{ }^{\circ} \mathrm{C}$, followed by a final elongation of $5 \mathrm{~min}$ at $72{ }^{\circ} \mathrm{C}$.

\section{Immunohistochemistry and light microscopy}

After decapitation, the skin overlying the penis was incised, and the whole penis body, including the CC crura and the bulbospongiosum covered by the ischiocavernous and bulbospongiosus skeletal muscles, was excised in one piece, fixed in Bouin's solution for $12 \mathrm{~h}$, and prepared for immunostaining (Gnessi et al. 1993, 2000). Immunostaining was carried out by incubating tissue sections $(3 \mu \mathrm{m})$ with TGF- $\beta_{1}$, PDGFs and PDGFRs antisera (1:100) overnight at $4{ }^{\circ} \mathrm{C}$ (Gnessi et al. 1993, Caprio 

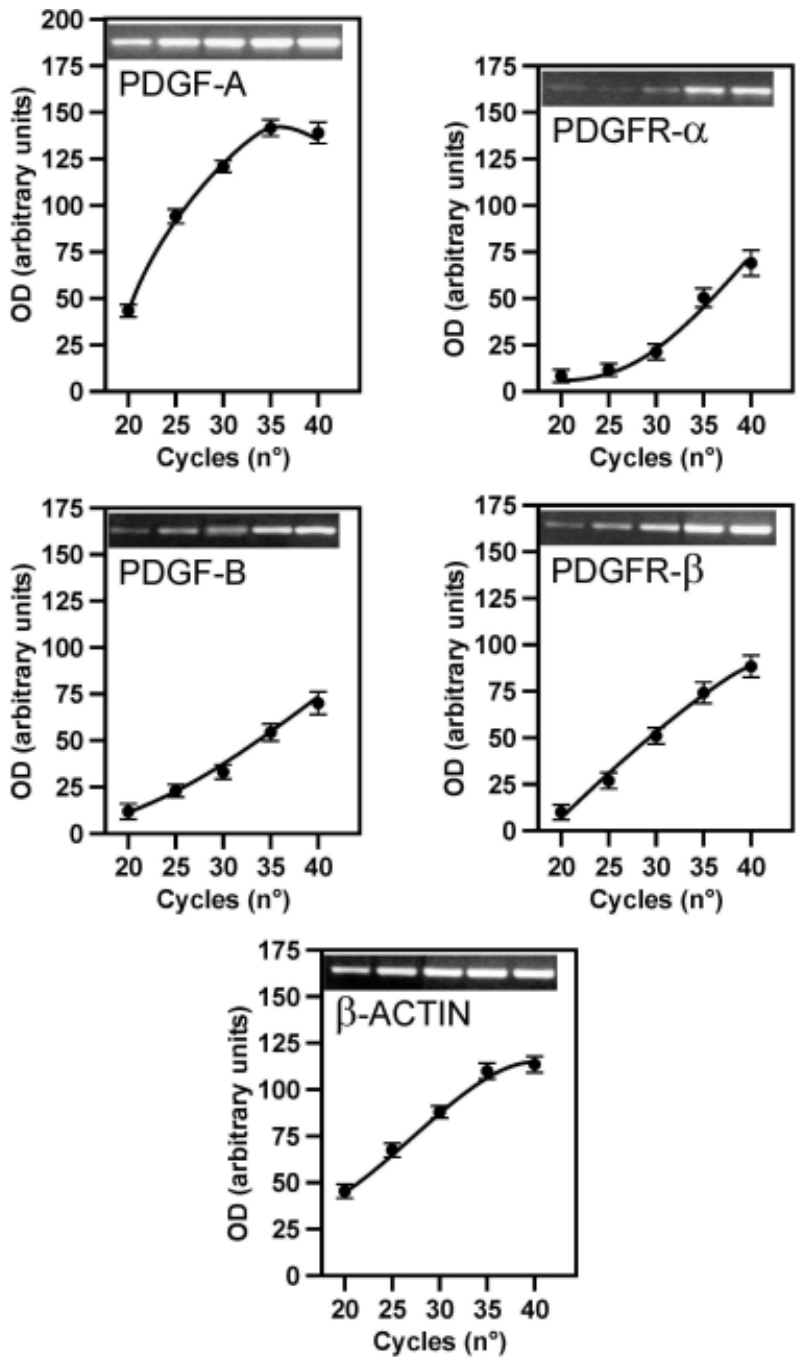

Figure 1 Optimization of RT-PCR conditions for semi-quantitative determination of hypoxic PDGFs and PDGFRs and $\beta$-actin mRNA. For amplification in the exponential phase of PCR, different numbers of cycles were tested for each message. Quantitative analysis of cycle-dependency for the generated PCR signals revealed a strong linear relationship between cycles 20 and 35 for PDGF-A (correlation coefficient $r^{2}=0.9889$ ) and between cycles 20 and 40 for other targets $\left(r^{2}=0.9778\right.$ for PDGFR- $\alpha, r^{2}=0.9840$ for PDGF-B, $r^{2}=0.9921$ for PDGFR- $\beta$, and $r^{2}=0.9442$ for $\beta$-actin). Values are given as means \pm S.D. of three independent determinations. A representative ethidium bromide-stained gel electrophoresis of the DNA products generated for each target is presented in the insets. OD, optical density.

et al. 1999). The following antisera were used: rabbit anti-human TGF- $\beta_{1}$ (Research Diagnostics, Inc., Flanders, NJ, USA), affinity purified polyclonal rabbit anti-PDGF-BB and anti-PDGF-AA antibodies (Genzyme, Cambridge, MA, USA); PDGFR-7 and PDGFR-3, rabbit polyclonal antisera to the PDGFR- $\alpha$ and $\beta$ subunit respectively (provided by Dr Carl-Henrik
Heldin, Ludwig Institute for Cancer Research, Uppsala, Sweden). PDGFR-7 was generated against a synthetic peptide covering amino acids 1066-1084 of the COOHterminal region of human PDGFR- $\alpha$ subunit and does not cross-react with the PDGFR- $\beta$ subunit. It recognizes both human and rat PDGFR- $\alpha$ subunit. PDGFR-3 was raised against a synthetic peptide corresponding to amino acids 981-994 of the mouse PDGFR- $\beta$. It recognizes rat PDGFR- $\beta$ subunit. PDGFR-7 and PDGFR-3 were affinity purified on columns with immobilized synthetic peptides against which the antisera were raised (Hermanson et al. 1992, Gnessi et al. 1995). All the antibodies react specifically with the respective antigens in immunoprecipitation and Western blotting experiments (Hermanson et al. 1992, Eccleston et al. 1993). For better identification of smooth muscle cells lining the cavernosal spaces, adjacent sections were immunostained with a primary antismooth muscle $\alpha$-actin antibody diluted up to $2 \mu \mathrm{g} / \mathrm{ml}$ at room temperature (DAKO Corp., Trappes, France). At the end of incubation immunopositivity was visualized by the streptavidin-biotin immunoperoxidase technique, using a commercial kit (Zymed Lab. Inc., San Francisco, CA, USA). Slides were developed using amino-ethylcarbazole (AEC) as chromogenic substrate that is converted by the peroxidase into a red to brownishred precipitate at the sites of antigen localization in the tissue. The preparations were counterstained with hematoxylin, dehydrated, cleared and mounted (ClaessonWelsh et al. 1989). The immunohistochemical expression of TGF- $\beta_{1}$ was used as a positive control of tissue hypoxia. Results were evaluated by using a semi-quantitative staining intensity of immunoreactive TGF- $\beta_{1}$, PDGF peptides and receptors on three consecutive sections of rat CC for each antisera were examined. We evaluated positive endothelial, perivascular smooth muscle and trabecular fibroblast cells counted on five microscopic cellular areas $(\times 40)$ for all sections of hypoxic and normoxic rat $\mathrm{CC}$. The positive staining intensity was scored on a four-tiered scale: negative $=0$; low intensity $=1$; moderate intensity $=2$; and strong intensity $=3$. The staining distribution and intensity were determined by two observers independently ( $\mathrm{P} \mathrm{V}$ and $\mathrm{M} \mathrm{A}$ ) with subsequent reconciliation of scored values. $\alpha$-actin immunostaining was considered as positive or negative (Gnessi et al. 1995, Visca et al. 1999). Thereafter, we calculated the overall means $(n=15$, resulting from evaluation of 5 microscopic cellular areas for three sections) of staining intensity for each cellular subtype of each hypoxic and normoxic CC examined. The total means of 150 scores $(15$ scores for ten hypoxic and normoxic rat CC respectively) of the staining intensity for each cellular components of hypoxic tissues were then compared with the total means of the 150 scores obtained from normoxic tissues. A score of zero was considered to be negative (-); mean scores between 0 and 1 were considered as weak staining intensity $(+/-)$; mean scores between $1 \cdot 1$ and 2 
Table 2 Comparative semi-quantitative staining intensity of immunoreactive TGF- $\beta_{1}$, PDGF peptides and receptors within the hypoxic and normoxic rat corpus cavernosum. Values in parentheses are means \pm S.E.

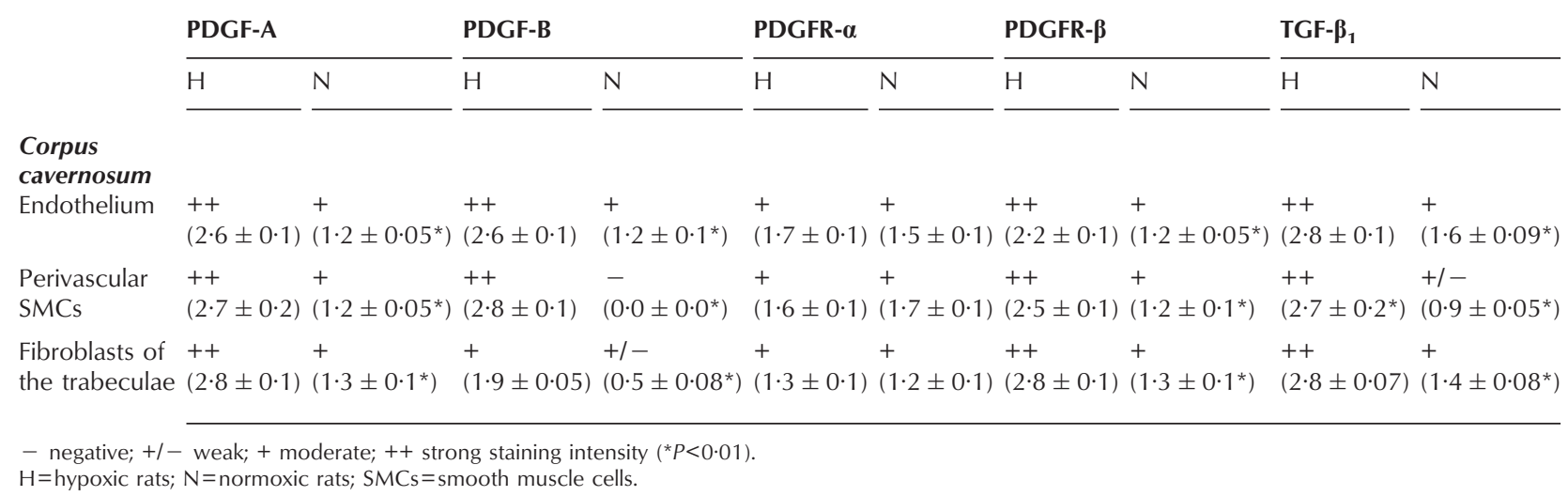

were considered as moderate staining intensity $(+)$; and mean scores between $2 \cdot 1$ and 3 were considered as strong staining intensity $(++)$ (see Table 2$)$.

\section{Statistical analysis}

Student's $t$-test for unpaired data was used for statistical analysis of the results. Data are presented as means \pm s.E. unless otherwise specified; $P$ values less than 0.05 were considered to be statistically significant.

\section{Results}

\section{Effects of generalized hypoxia on blood gas parameters}

After euthanization, hypoxic rats had higher $\mathrm{pCO}_{2}$ and lower arterial $\mathrm{pO}_{2}$ than control animals $(80 \cdot 1 \pm 3 \cdot 2$ vs $50 \cdot 7 \pm 2 \cdot 1 \mathrm{mmHg}, P<0 \cdot 001$, and $20 \cdot 2 \pm 5 \cdot 1$ vs $48 \cdot 3 \pm 4 \cdot 0$ $\mathrm{mmHg}, \quad P<0.001$ respectively) as well as lower $\mathrm{sO}_{2}$ $(17 \% \pm 7 \%$ vs $70 \% \pm 5 \%, P<0 \cdot 001)$.

\section{PDGF and PDGFRs $m R N A$ expression in isolated rat $C C$}

Figure 1 shows the linearity of PCR response for each individual primer in hypoxic tissues. The linearity of PCR response in normoxic tissues was similar (data not shown). Semi-quantitative RT-PCR analysis of mRNA extracted from $\mathrm{CC}$ of the rat penis showed higher amounts of PDGF-A, PDGF-B and PDGFR- $\beta$ mRNA transcripts in hypoxic versus control rats $(P<0 \cdot 001)$; no differences were found in PDGFR- $\alpha$ mRNA expression (Fig. 2, upper and lower panel). Hypoxia did not modify $\beta$-actin content.

\section{Immunohistochemical localization of TGF- $\beta_{1}, P D G F$ and PDGFRs in rat CC}

Immunohistochemical localization of PDGF-A, PDGF-B, PDGFR- $\alpha$, PDGFR- $\beta$ and TGF- $\beta_{1}$ in CC both after acute hypoxia and in normal conditions is shown in Fig. 3.
In normoxic rats staining for PDGF peptides and receptors and TGF- $\beta_{1}$ occurred in endothelial cells, perivascular smooth muscle cells and in the fibroblasts of the connective trabecular structures of the CC (Fig. 3B,D,F,H,J). For all peptides, cytoplasmic localization was focal in the endothelium, diffuse in the perivascular smooth muscle cells and perinuclear in the fibroblasts of the trabeculae of overall CC examined. The immunohistochemical localization in hypoxic animals was similar (Fig. 3A,C,E, G,J). The semi-quantitative comparison of staining intensities showed that in the endothelial cells PDGF peptides, PDGFR- $\beta$ and TGF- $\beta_{1}$ immunoreactivity was more intense in hypoxic versus normoxic rat CC (Table 2). Perivascular smooth muscle cells, which also stained for $\alpha$-actin (data not shown), showed a stronger signal in hypoxic versus normoxic rat for PDGF-A, PDGF-B and PDGFR- $\beta$; on the contrary, PDGFR- $\alpha$ staining intensity was not modified. The staining pattern in fibroblasts of the connective trabecular structures was similar to that described for the endothelium (Table 2). In hypoxic rat $\mathrm{CC}$ the TGF- $\beta_{1}$ immunostaining was more intense in all structures when compared with normoxic rats (Table 2 and Fig. 3I,J).

\section{Discussion}

The trabecular smooth muscle cells of the CC regulate penile vasoconstriction and vasodilation, and consist primarily of smooth muscle and extracellular connective tissue matrix delimitating vascular lacunae lined by the endothelium. The volumetric contribution of the corporal endothelium and autonomic nerves is considered to be negligible. The percent trabecular smooth muscle content in normal patients has been reported to range from 42 to 50\% (Moreland et al. 1995). In vasculogenically impotent patients a decrease in the percentage of trabecular smooth muscle content has been described, with levels ranging 

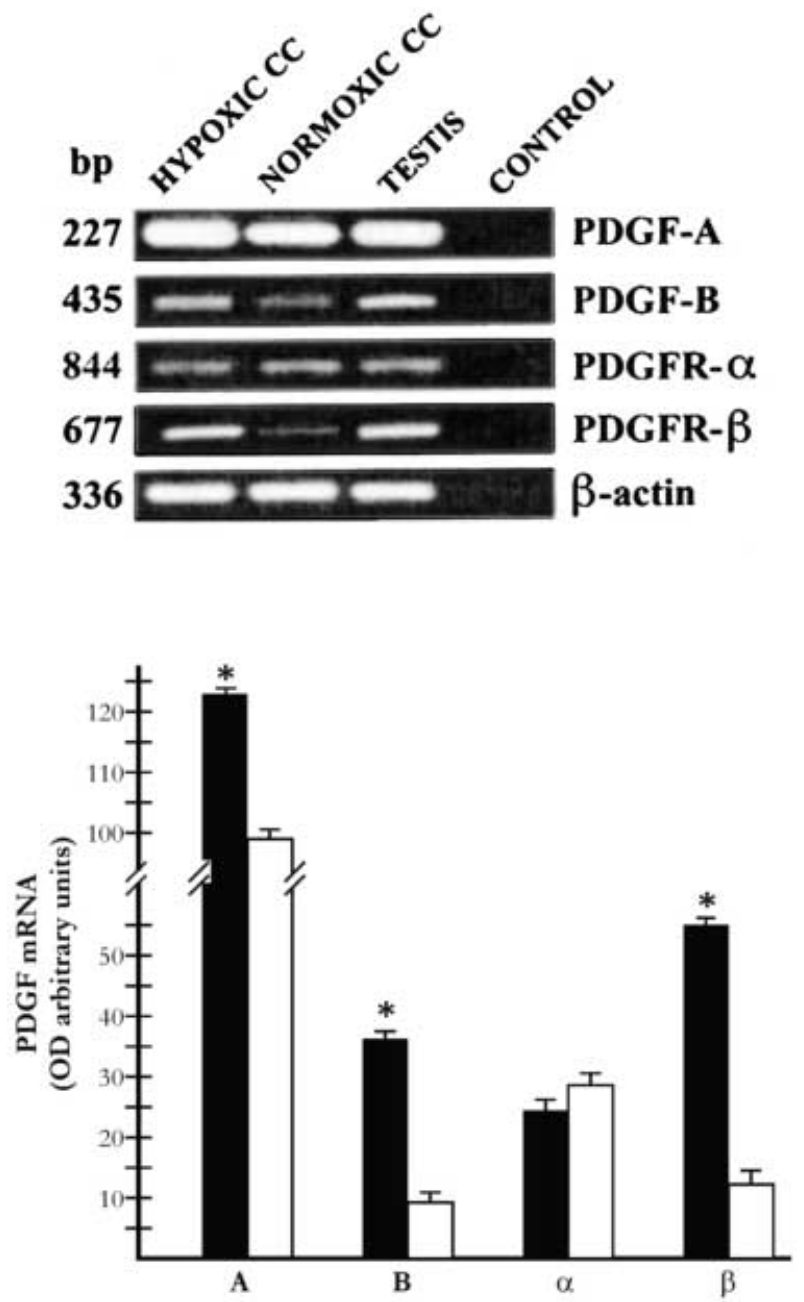

Figure 2 Upper panel, RT-PCR expression analysis of PDGF peptides and PDGF receptors in corpus cavernosum of hypoxic and normoxic rats, in rat testis (positive control) and in the absence of cDNA template (negative control). All data were normalized for $\beta$-actin (internal control) and quantified by densitometry computer software. Lower panel, mean densitometric analysis of the results obtained from three consecutive experiments; the S.E. was less than $10 \%\left({ }^{*} P<0 \cdot 001\right)$. Solid bars indicate hypoxic and open bars indicate normoxic rats. OD, optical density.

from 28 to $35 \%$ out of normal content; also, it has been shown that in CC the relative amount of trabecular smooth muscle content is regulated by oxygen tension via activation of nitric oxide pathway (Kim et al. 1993, Kourembanas et al. 1997).

Here we evaluated for the first time the PDGF peptides and PDGF receptor expression in the rat CC after transient in vivo hypoxia in order to determine whether changes in oxygen tension may alter their expression inside the penis and be involved in the pathogenesis of CC fibrosis. Previous studies have shown that hypoxia stimulates PDGF expression in the rat lungs and may be involved in the pathogenesis of idiopathic pulmonary fibrosis (Katayose et al. 1993, Betsholtz \& Raines 1997). Moreover, incubation under hypoxic conditions stimulates the release of PDGF from human macrophages and cultured endothelial cells (Kuwabara et al. 1995, Betsholtz \& Raines 1997), as well as strongly up-regulates the PDGF-B chain gene expression (Kourembanas et al. 1990). In normal penile human tissues, vasal endothelial cells constitutively express PDGF; furthermore, fibroblasts from pathological tunica albuginea of impotent men with Peyronie's disease and venocclusive dysfunction show intense immunostaining for PDGF-A and -B chains (Gentile et al. 1996). As a consequence, a higher expression of PDGF-A and -B proteins may determine an imbalance between trabecular smooth muscle and connective tissue ratio resulting in $\mathrm{CC}$ fibrosis and erectile dysfunction. In our study, we found that PDGF and PDGFR are constitutively expressed in the rat vascular endothelial cells as well as in penile nerves. More important, in the corpora of hypoxic rats there was a higher expression of PDGF-A and -B proteins than in normoxic rats. Immunohistochemistry showed that the expression was focal in the endothelium, diffuse in the perivascular smooth muscle cells and perinuclear in the fibroblasts of the trabeculae. After exposure to transient low oxygen tension, PDGFR- $\beta$ expression was also increased in the same cell components of CC expressing PDGF peptides, suggesting that in this condition these cells become a more sensitive target for PDGF peptides. The absence of modifications in PDGFR- $\alpha$ expression may be explained with the concomitant overexpression of TGF- $\beta_{1}$ which is known to down-regulate PDGFR- $\alpha$ in human fibroblasts (Bonner et al. 1995, Kuwabara et al. 1995). Thus, the PDGF overexpression in penile structures under transient hypoxia may well contribute to the cascade of events leading to tissue fibrosis under chronic hypoxic conditions. These events may occur in some patients with erectile dysfunction in which a chronic CC hypoxia has been reported (Tarhan et al. 1997).

In the rat, it has been demonstrated that growth factors may be involved in the autocrine/paracrine loop involved in tissue fibrosis (Battegay et al. 1990). TGF- $\beta_{1}$ is overexpressed in tissues chronically exposed to experimental hypoxia and has a key role in determining lung and kidney fibrosis (Border \& Noble 1994). In cultured human CC smooth muscle cells, TGF- $\beta_{1}$ stimulates the synthesis of fibrillar collagen (Moreland 1998) and it has been involved in the increased collagen trabecular smooth muscle cell synthesis that occurs under hypoxic conditions (Moreland et al. 1995). Furthermore, intrapenile oxygen tensions consistent with flaccid blood $\mathrm{pO}_{2}(30 \mathrm{mmHg})$ increase TGF- $\beta_{1}$ mRNA expression by approximately twofold in $18 \mathrm{~h}$ and threefold in $24 \mathrm{~h}$ in men (Moreland 1998). Accordingly, we found that exposure of penile tissue to transient low blood $\mathrm{pO}_{2}(\sim 20 \mathrm{mmHg})$ in vivo led to an 

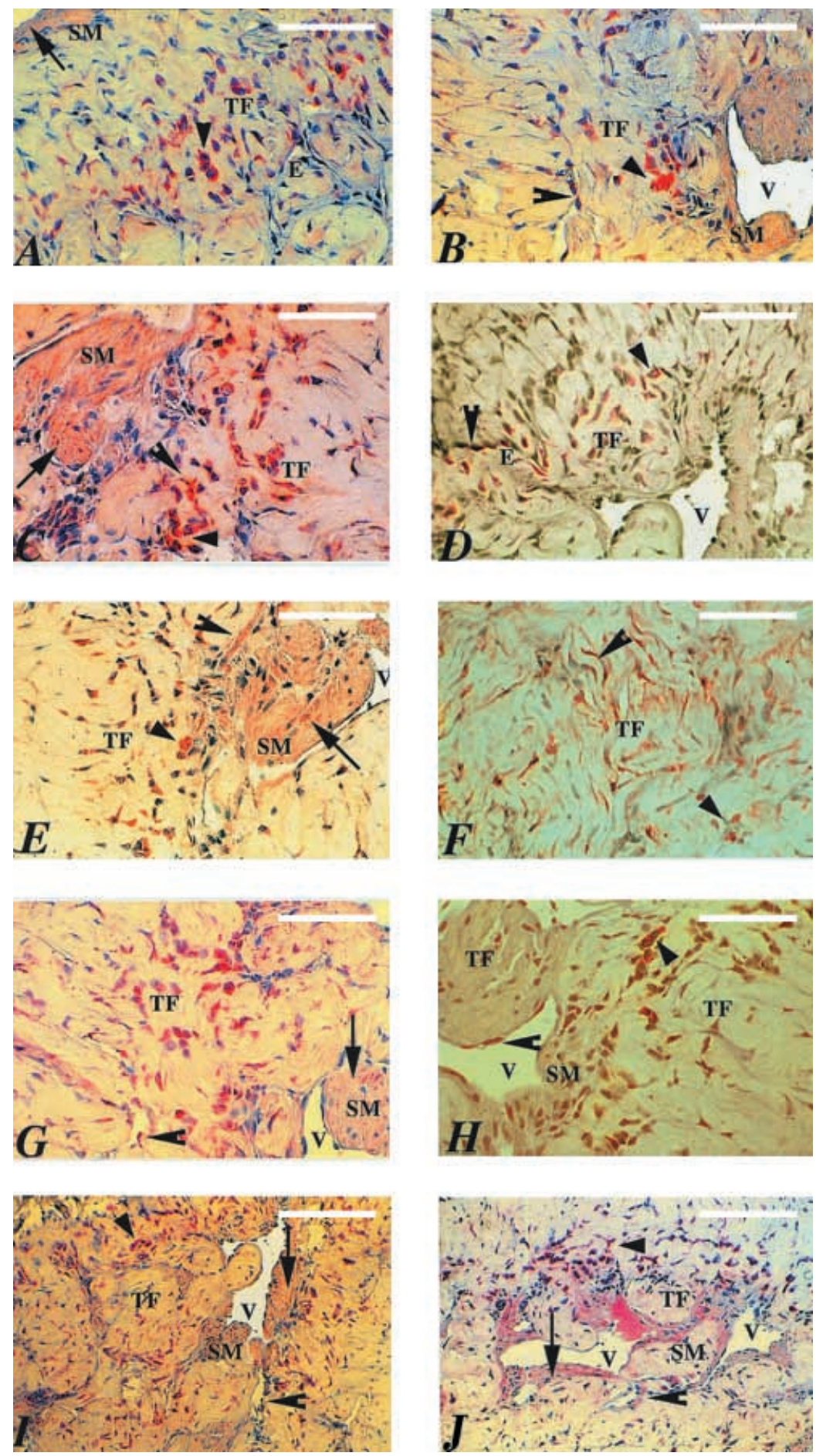

Figure 3 Immunohistochemical staining pattern of PDGF-A $(A, B),-B(C, D)$ and PDGFR- $\alpha(E, F)$ and $-\beta(G, H)$ with affinity-purified antibody in cross-sections of hypoxic $(A, C, E, G)$ by comparison with normoxic $(B, D, F, H)$ rat corpus cavernosum, counterstained with hematoxylin. The expression was intense in the cytoplasm of trabecular fibroblasts (triangles) and endothelial cells (arrowheads), and more diffuse in smooth muscle cells (arrows). The scale bar in A represents $25 \mu \mathrm{m}$ and applies to $A$ - $H$. Sections of rat corpus cavernosum immunostained for TGF- $\beta_{1}$ in hypoxic $(I)$ and normoxic $(J)$ conditions are also shown. The scale bar in $I$ represents $50 \mu \mathrm{m}$ and also applies to . $\mathrm{TF}=$ fibroblasts of the trabeculae; $\mathrm{E}=$ endothelium; $\mathrm{V}=$ vessel; $\mathrm{SM}=$ smooth muscle cells. 
increased TGF- $\beta_{1}$ immunostaining in the rat penile CC, suggesting that multiple genes encoding matrix molecules leading to fibrotic alterations inside the penis may be activated even during transient hypoxia, similar to that described in the endothelium (Gerritsen \& Bloor 1993).

Low-low priapism is a frequent complication of vasoactive intracavernous pharmacotherapy in men affected by erectile dysfunction, especially when combination drugs are used (Fabbri et al. 1997). Human CC undergo major ultrastructural changes, i.e. corporeal fibrosis during priapism, but pharmacological detumescence is not recommended until $12 \mathrm{~h}$ has passed (Hauri et al. 1983). However, it is known that in a rabbit model, hypoxia induced by prolonged erection and subsequent local acidosis impair contractility of trabecular smooth muscles. This phenomenon impedes the drainage of blood, perpetuates the ischemic state and may cause early ultrastructural changes (Kim et al. 1996, Saenz de Tejada et al. 1997, Moon et al. 1999). Taking into account our findings, the risk that fibrotic alterations may begin early after acute hypoxia has occurred inside the corpora is quite elevated. Thus, in the clinical outpatient setting prompt detumescence of erections that exceed a duration of $2 \mathrm{~h}$ should be recommended (Aversa et al. 2000).

In conclusion, transient in vivo hypoxia increases the expression of the PDGF system in the rat penis. It is conceivable that these changes may occur also in conditions of chronic hypoxia in men and may lead to alterations in penile structures similar to those already described in other organs (Wespes et al. 1998, Okabe et al. 1999). These phenomena might contribute to the pathogenesis of erectile dysfunction that frequently complicate atherosclerosis, diabetes mellitus, hypertension, obstructive pulmonary disease and intense cigarette smoking.

\section{Acknowledgements}

We thank Dr Massimiliano Caprio for the critical reading of the manuscript. Presented at the 81st International Congress of the Endocrine Society, 12-15 June, San Diego, CA, 300, 1999, P2-91.

\section{References}

Antoniades HN 1991 PDGF: a multifunctional growth factor. Baillieres Clinical Endocrinology and Metabolism 5 595-613.

Aversa A, Bonifacio V, Moretti C, Frajese G \& Fabbri A 2000 Re-dosing of prostaglandin- $\mathrm{E}_{1}$ versus prostaglandin- $\mathrm{E}_{1}$ plus phentolamine in male erectile dysfunction: a dynamic color power Doppler study. International Journal of Impotence Research 12 33-40.

Battegay EJ, Raines EW, Seifert RA, Bowen-Pope DF \& Ross R 1990 TGF-beta induces bimodal proliferation of connective tissue cells via complex control of an autocrine PDGF loop. Cell 63 515-524.

Betsholtz C \& Raines EW 1997 Platelet-derived growth factor: a key regulator of connective tissue cells in embryogenesis and pathogenesis. Kidney International 51 1361-1369.
Bonner JC, Badgett A, Lindroos PM \& Osornio-Vargas AR 1995 Transforming growth factor beta 1 downregulates the plateletderived growth factor-alpha-receptor subtype on human lung fibroblasts in vitro. American Journal of Respiratory Cell and Molecular Biology 13 496-505.

Border WA \& Noble NA 1994 Mechanisms of disease: transforming growth factor- $\beta$ in tissue fibrosis. New England Journal of Medicine 331 1286-1292.

Broderick GA, Gordon D, Hypolite J \& Levin RM 1994 Anoxia and corporeal smooth muscle dysfunction: a model for ischemic priapism. Journal of Urology 151 259-262.

Bucher M, Sandner P, Wolf K \& Kurtz A 1996 Cobalt but not hypoxia stimulates PDGF gene expression in rats. American Journal of Physiology. Endocrinology and Metabolism 271 E451-E457.

Bunn HF \& Poyton RO 1996 Oxygen sensing and molecular adaptation to hypoxia. Physiological Reviews 76 839-885.

Caprio M, Isidori AM, Carta AR, Moretti C, Dufau ML \& Fabbri A 1999 Expression of functional leptin receptors in rodent Leydig cells. Endocrinology 140 4939-4947.

Claesson-Welsh L, Hammacher A, Westermark B, Heldin CH \& Nister M 1989 Identification and structural analysis of the type A receptor for platelet-derived growth factor: similarity with the type B receptor. Journal of Biological Chemistry 264 1742-1747.

Eccleston PA, Funa K \& Heldin CH 1993 Expression of platelet-derived growth factor (PDGF) and PDGF $\alpha$ - and $\beta$-receptors in the peripheral nervous system: an analysis of sciatic nerve and dorsal root ganglia. Developmental Biology 155 459-470.

El-Sakka AI, Hassoba HM, Pillarisetty RJ, Dahiya R \& Lue TF 1997 Peyronie's disease is associated with an increase in transforming growth factor- $\beta$ protein expression. Journal of Urology $\mathbf{1 5 8}$ 1391-1394.

Fabbri A, Aversa A \& Isidori A 1997 Erectile dysfunction: an overview. Human Reproduction Update 3 455-466.

Faller DV 1999 Endothelial cell responses to hypoxic stress. Clinical and Experimental Pharmacology and Physiology 26 74-84.

Franchini KG, Cestari IA \& Krieger EM 1994 Restoration of arterial blood oxygen tension increases arterial pressure in sinoaotricdenervated rats. American Journal of Physiology 226 H1055-H1061.

Gentile V, Modesti A, La Pera G, Vasaturo F, Modica A, Prigiotti G, Di Silverio F \& Scarpa S 1996 Ultrastructural and immunohistochemical characterization of the tunica albuginea in Peyronie's disease and veno-occlusive dysfunction. Journal of Andrology 17 96-103.

Gerritsen ME \& Bloor CM 1993 Endothelial cell gene expression in response to injury. FASEB Journal 7 523-532.

Gnessi L, Emidi A, Scarpa S, Palleschi S, Ragano-Caracciolo M, Silvestroni L, Modesti A \& Spera G 1993 Platelet-derived growth factor effects on purified testicular peritubular myoid cells: binding, cytosolic $\mathrm{Ca}^{2+}$ increase, mitogenic activity and extracellular matrix production enhancement. Endocrinology 133 1880-1890.

Gnessi L, Emidi A, Jannini EA, Carosa E, Maroder M, Arizzi M, Ulisse S \& Spera G 1995 Testicular development involves the spatiotemporal control of PDGFs and PDGF receptors gene expression and action. Journal of Cellular Biology 4 1105-1121.

Gnessi L, Basciani S, Mariani S, Arizzi M, Spera G, Wang C, Bondjers C, Karlsson L \& Betsoltz C 2000 Leydig cell loss and spermatogenic arrest in platelet-derived growth factor (PDGF)A-deficient mice. Journal of Cellular Biology 1491019 1025.

Hauri D, Spycher M \& Bruhlmann W 1983 Erection and priapism: a new physiopathological concept. Urology International 38 138-145.

Heldin CH 1992 Structural and functional studies on platelet-derived growth factor. EMBO Journal 11 4251-4259.

Hermanson M, Funa K, Hartman M, Claesson-Welsh L, Heldin CH, Westermark B \& Nister M 1992 Platelet-derived growth factor and 
its receptors in human glioma tissue: expression of messenger RNA and protein suggests the presence of autocrine and paracrine loop. Cancer Research 52 3213-3219.

Katayose D, Ohe M, Yamauchi K, Ogata M, Shirato K, Fujita H, Shibahara S \& Takishima T 1993 Increased expression of PDGF A- and B-chain genes in rat lungs with hypoxic pulmonary hypertension. American Journal of Physiology 264 L100-L106.

Kim N, Vardi Y, Padma-Nathan H, Daley J \& Saenz de Tejada I 1993 Oxygen tension regulates the nitric oxide pathway. Physiological role in penile erection. Journal of Clinical Investigation 91 437-442.

Kim NN, Kim JJ, Hypolite J, Garcia-Diaz JF, Broderick GA, Tornheim K, Daley JT, Levin R \& Saenz de Tejada I 1996 Altered contractility of rabbit penile corpus cavernosum smooth muscle by hypoxia. Journal of Urology 155 772-778.

Kourembanas S, Hannan RL \& Faller DV 1990 Oxygen regulates the expression of the platelet-derived growth factor-B chain gene in human endothelial cells. Journal of Clinical Investigation $\mathbf{8 6}$ $670-674$.

Kourembanas S, Morita T, Liu Y \& Christou H 1997 Mechanisms by which oxygen regulates gene expression and cell-cell interaction in the vasculature. Kidney International 51 438-443.

Kuwabara K, Ogawa S, Matsumoto M, Koga S, Clauss M, Pinsky DJ, Lyn P, Leavy J, Witte L, Joseph-Silverstein J et al. 1995

Hypoxia-mediated induction of acidic/basic fibroblast growth factor platelet-derived growth factor in mononuclear phagocytes stimulates growth of hypoxic endothelial cells. PNAS 9 4606-4610.

Moon DG, Lee DS \& Kim JJ 1999 Altered contractile response of penis under hypoxia with metabolic acidosis. International Journal of Impotence Research 11 265-271.

Moreland RB, Traish A, McMillin MA, Smith B, Goldstein I \& Saenz de Tejada I $1995 \mathrm{PGE}_{1}$ suppresses the induction of collagen synthesis by transforming growth factor- $\beta_{1}$ in human corpus cavernosum smooth muscle. Journal of Urology 153 826-834.
Moreland RB 1998 Is there a role of hypoxemia in penile fibrosis: a viewpoint presented to the Society for the Study of Impotence. International Journal of Impotence Research 10 113-120.

Nehra A, Goldstein I, Pabby A, Nugent M, Huang YH, De las Morenas A, Krane RJ, Udelson D, Saenz de Tejada I \& Moreland RB 1996 Mechanisms of venous leakage: a prospective clinicopathological correlation of corporeal function and structure. Journal of Urology 156 1320-1329.

Okabe H, Hale TM, Kumon H, Heaton JPW \& Adams MA 1999 The penis is not protected - in hypertension there are vascular changes in the penis which are similar to those in other vascular beds. International Journal of Impotence Research 11 133-140.

Saenz de Tejada I, Kim NH, Daley JT, Royai R, Hypolite J, Broderick GA, Garcia-Diaz F \& Levin R 1997 Acidosis impairs rabbit trabecular smooth muscle contractility. Journal of Urology 157 722-726.

Tarhan F, Kuyumcuoglu U, Kolsuz A, Ozgul A \& Canguven O 1997 Cavernous oxygen tension in the patients with erectile dysfunction. International Journal of Impotence Research 9 149-153.

Visca P, Alò PL, Del Nonno F, Botti C, Trombetta G, Marandino F, Filippi S, Di Tondo U \& Perrone-Donnorso R 1999 Immunohistochemical expression of fatty acid synthase, apoptoticregulating genes, proliferating factors, and ras protein product in colorectal adenomas, carcinomas, and adjacent nonneoplastic mucosa. Clinical Cancer Research 5 4111-4118.

Wespes E, Raviv G, Vanegas JP, Decaestecker C, Petein M, Danguy A, Schulman CC \& Kiss R 1998 Corporeal veno-occlusive dysfunction: a distal arterial pathology? Journal of Urology 160 2054-2057.

Williams LT 1989 Signal transduction by the platelet-derived growth factor. Science 243 1564-1570.

Received 29 March 2001

Accepted 26 April 2001 